\title{
The role of openness in collaborative innovation in industrial networks: historical and contemporary cases
}

\author{
Fens Laage-Hellman and Frida Lind \\ Department of Technology Management and Economics, Chalmers University of Technology, Gothenburg, Sweden, and \\ Andrea Perna \\ Department of Management, Università Politecnica delle Marche, Ancona, Italy and Division of Industrial Engineering and \\ Management, Department of Civil and Industrial Engineering, Uppsala University, Uppsala, Sweden
}

\begin{abstract}
Purpose - This paper aims to explore the role and meaning of openness for the purpose of enhancing the understanding of collaborative innovation from an industrial network perspective.

Design/methodology/approach - The theoretical framework is based on the Industrial Network Approach, and the concepts of activity links, resource ties and actor bonds are used as a starting point for capturing the content and dynamics of the interaction. The empirical part consists of five case studies: two historical and three contemporary cases dealing with collaborative innovation projects. The cases are analyzed with regard to openness in business relationships and their connections in the network.

Findings - The main contribution is a conceptualization of openness in business relationships and relationship connections. The paper describes various forms and contents of openness - and closeness. It is postulated that the concept of openness can be used as an analytical tool for digging deeper into relationship and network-related issues of relevance to firms' behavior in the context of collaborative innovation. Openness, as it is defined in this paper, is also put forward as an explanation of why (or why not) collaborative innovation projects become successful.

Originality/value - The conceptualization of openness differs from openness as it is commonly described in the open innovation literature. There, openness is the opposite of closeness, that is, a pattern where the innovation activities take place internally within the company. In this paper, openness, instead, has to do with how firms interact with other network actors in the context of collaborative innovation.
\end{abstract}

Keywords Interaction, Collaborative innovation, Resource combining, Openness, Business relationship, Industrial network, Open innovation

Paper type Research paper

\section{Introduction}

This paper focuses on collaborative innovation in business-tobusiness (B2B) markets. The important role of interorganizational collaboration, interaction and exchange in technological innovation has long been recognized in economics and business management. It has been given prominence in many publications in different sub-disciplines. These include economics of innovation (Freeman, 1982), history of technology (Rosenberg, 1976, 1982), innovation systems (Nelson, 1993; Edquist, 1997), clusters (Porter, 1998; Cooke, 2001), product development (Rothwell et al., 1974; von Hippel, 1988), innovation management (Teece, 1986) and B2B marketing (Håkansson, 1987; Bidault, 1998; Håkansson and Waluszewski, 2002). Collaborative innovation is thus a phenomenon dealt with from different theoretical perspectives using a variety of research methods.

The current issue and full text archive of this journal is available on Emerald Insight at: https://www.emerald.com/insight/0885-8624.htm

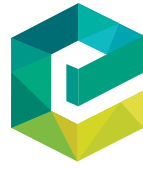

Journal of Business \& Industrial Marketing 36/13 (2021) 116-128

Emerald Publishing Limited [ISSN 0885-8624] [DOI 10.1108/JBIM-10-2020-0462]
Since the mid-1980s, numerous studies dealing with this topic in B2B markets based on the Industrial Network Approach (INA) have been carried out (Baraldi et al., 2012b; Laage-Hellman et al., 2014). Håkansson (1987) is a pioneering book presenting some early studies. The INA research has shown that companies operating in B2B markets can be seen as actors in industrial (or business) networks where the commercial transactions take place within more or less longlasting business relationships. Furthermore, to a large extent, the technological development takes place through innovation processes where selling and buying companies interact and collaborate with each other. Business relationships are thus important not only for the running commercial exchange but

\footnotetext{
(C) Jens Laage-Hellman, Frida Lind and Andrea Perna. Published by Emerald Publishing Limited. This article is published under the Creative Commons Attribution (CC BY 4.0) licence. Anyone may reproduce, distribute, translate and create derivative works of this article (for both commercial and non-commercial purposes), subject to full attribution to the original publication and authors. The full terms of this licence maybe seen at http://creativecommons.org/licences/by/4.0/legalcode
}

Received 11 October 2020

Revised 18 January 2021

12 March 2021

Accepted 22 March 2021 
also for the development of new products, services and production processes (see, e.g. La Rocca and Snehota, 2014; Dubois and Araujo, 2006).

In recent years, the concept of openness has attracted a great deal of interest among innovation researchers. Openness, in general terms, refers to the lack of restriction and secrecy. In the innovation context in particular, starting with Henry Chesbrough's pioneering book from 2003, open innovation (OI) and openness have emerged as rapidly expanding streams of literature focusing on how firms can become more innovative by using internal resources together with external resources (primarily knowledge) provided by others (firms, consumers, inventors, academic researchers, etc.). The core idea is that, to create an innovation, firms should enable knowledge flows across their boundaries both inwards and outwards. Moreover, the role of openness in innovation has been studied with a focus on the number of partners (Dahlander and Gann, 2010), dimensions of openness (Öberg and Alexander, 2019) and the need for absorptive capacity (Cohen and Levinthal, 1990; Alisghar et al., 2019, p. 82).

Business interaction, relationships and networking appear to be central elements in OI. However, so far, openness in collaborative innovation has rarely been explicitly dealt with in studies on business relationships and networks. There are some exceptions though such as Hasche et al. (2017) highlighting the role of trust in open collaborative innovation and Lind et al. (2012) who focus on resource interaction across the boundary of inter-organizational projects. In this paper, we set out to explore the role and meaning of openness for the purpose of enhancing the understanding of collaborative innovation in B2B markets. Openness will be explored focusing on the following questions: In what ways are firms open (or not open) when they collaborate with external actors? How does the degree of openness vary depending on the situation; for example, whether the relationship is an existing one or a new one? How can the degree of openness change over time, and why? The degree of openness can vary depending on the project's needs and the actors' willingness and ability to interact with externals (La Rocca and Perna, 2014; Lind, 2015).

Hence, this paper aims to clarify what openness means from an INA point of view and show how inclusion of the openness concept in the study of collaborative innovation can lead to a better understanding of firms' interactive behavior. Companies carry out many types of interaction activities in networks (see, e.g. Ford et al., 2010) and the question is, for example, which of these activities are important from an openness point of view and how companies deal with related opportunities and challenges. This aim is achieved by using INA-based case studies of industrial firms' collaborative innovation projects. The methodology includes both historical and contemporary cases shedding light, for example, on the fact that this way of innovating is not new.

In this paper, we define openness as innovating companies' sharing and combining of resources with others through interaction processes. The degree of openness varies from case to case depending on the actors' willingness and ability to be open and the specific needs of the project. Thus, openness is concerned with how firms interact in industrial networks - what they actually do in specific relationships as well as what they choose to not do. Lack of openness can be understandable or rational in certain situations while in other situations it can have undesirable consequences.

The paper is structured as follows. In the next section, we provide our theoretical frame of reference which builds on INA as well as OI literature. Then follows a description of the methodology, after which we present five cases. In the subsequent case analysis, we elaborate on openness in industrial networks. The paper continues with a concluding discussion, where we present a set of propositions, and ends with implications and suggestions for further research.

\section{Theoretical frame of reference}

\subsection{Technological development in industrial networks}

The INA constitutes the main theoretical starting point. It has its origin in many years of research on marketing and purchasing in B2B markets (see, e.g. Håkansson, 1982; Håkansson and Snehota, 1995; Håkansson et al., 2009). The focus is on industrial networks made up of connected business relationships that link selling and buying firms and enable an effective commercial exchange. These relationships and networks in many situations play an important role for technological development (see, e.g. Håkansson, 1987, 1990; Biemans, 1992; Håkansson and Waluszewski, 2002, 2007).

Actors, resources and activities (ARA) are three key concepts (Håkansson and Snehota, 1995). The actors (e.g. firms) use different types of resources and carry out activities, internally as well as jointly with others. As regards technological innovation, much of the research focuses on resources and how these can be used and developed (Ingemansson, 2010; Prenkert et al., 2019; Sundquist and Melander, 2020). Resources are elements that have a known or potential use value for someone (ibid.; Holmen, 2001). In accordance with the resource heterogeneity assumption (Penrose, 1959; Alchian and Demsetz, 1972), the value of resources depends on how they are combined with other resources. The resource combining can take place not only internally within a firm, but also across organizational boundaries. Useful resources in the form of, for example, knowledge, products and facilities are distributed among different actors in the network. It is thus by combining such resources through inter-organizational interaction processes that innovation can be successfully achieved.

Hence, resource development in industrial networks requires the combination of resources - knowledge and physical objects such as prototypes and equipment - held by different actors. When developing new products, for example, there is a need for situation-specific knowledge about the intended use of the product and how it can be designed and manufactured. To succeed with product development, it is usually not enough to have knowledge and other resources transferred across organizational boundaries. Very often, effective resource combining requires that resource elements are brought together and used in $\mathrm{R} \& \mathrm{D}$ activities carried out jointly by two or more actors who have established collaborative relationships with each other. Depending on the needs, the interaction can be extensive and long term and lead to co-creation in a true sense or be limited in time and scope.

The past three decades of extensive research on technological innovation in industrial networks constitutes the theoretical background to the present paper. It has given us knowledge, inter alia, about the role and functioning of supplier relationships 
(Pedersen, 1996; Gadde and Snehota, 2000; Johnsen and Ford, 2007; Melander, 2014) and customer relationships (Ritter and Walter, 2003; Öberg, 2010). In more recent years, growing interest can be observed in start-up companies and their interactions with various types of counterpart (Aaboen et al., 2017; Baraldi et al., 2019; Laage-Hellman et al., 2020).

\subsection{Openness in the open innovation literature}

According to the seminal book by Henry Chesbrough (2003), Open Innovation: The New Imperative for Creating and Profiting from Technology, OI means that the firm's boundary is perforated, allowing a flow of resources, primarily knowledge, inwards and outwards. This makes it possible for the firm to have its own resources combined with external resources in value-creating innovation processes. The innovation takes place within the focal firm in the case of inbound flows and outside in the case of outbound flows. Recognizing the advantage of exploiting internal knowledge in combination with external knowledge dispersed in the business environment, Chesbrough argues that companies should change their perspective on how they innovate (ibid.). The OI model thus rests on the idea that it is possible for the focal firm "to strike a balance between the inbound and outbound dimensions of an open innovation strategy" (Bahemia and Squire, 2010, p. 605).

The OI literature is dominated by a company-centric view on managing innovation (Trott and Hartmann, 2009; Öberg, 2016). Even though multiple actors are involved, OI is usually seen as an internal process that can be autonomously managed by the focal firm (Elmquist et al., 2009). It is the latter that purposely manages the knowledge flows and decides what level of openness that should be reached (Laursen and Salter, 2006; Chesbrough and Bogers, 2014). Thus, the focal firm decides when and how it wants to interact with the external actors. Those are, according to Drechsler and Natter (2012), always available in the environment and ready to be captured. This means that after having scanned the environment, the focal firm can select which external resources it would like to bring in and combine with the internal resources. In this way, a nearly perfect balance between the internal and external resources can be achieved.

In later publications, the view of the interaction has been broadened and there is more emphasis on collaboration. For example, Enkel et al. (2009) stress the importance for the focal firm of having the capability to set up "focused" collaborations with promising counterparts. The identification of coupled innovation as a third type of OI process (besides outside-in and inside-out) can be interpreted as a step in the same direction. This process "refers to co-creation with (mainly) complementary partners through alliances, cooperation, and joint ventures during which give and take actions are crucial for success" (ibid., p. 313). West and Bogers (2014) state that the role of customers and suppliers in OI is a relevant but understudied topic. They call for taking an interactive perspective to understand how actors mutually collaborate. However, Chesbrough et al. (2018) point to an important difference between OI and inter-organizational network studies by stating that "open innovation often involves collaboration among a large number of loosely coupled actors who rarely meet in person and often do not continue working together" (p. 936). This indicates that the empirical phenomena dealt with in many OI studies differ from what we focus on in the INA-based research.

\subsection{Research questions}

To explore the meaning of openness (as defined in the introductory section) from an INA perspective, we distinguish between dyadic interaction and relationship connections (Håkansson and Snehota, 1995). Thus, the first research question concerns openness in dyadic interactions. Here we use the concepts activity links, resource ties and actor bonds which are central to the ARA model introduced above (ibid.). Links arise when activities (e.g. production or R\&D) carried out by the interacting parties are coordinated and adapted. Adaptation of resources (e. g. products or knowledge) leads to the formation of ties. Bonds are related to how the actors are bonded informally (e.g. socially) and formally (e.g. through contracts). These links, ties and bonds are the outcome of interaction and at the same time they affect future interactions. The formation of links, ties and bonds thus reflects how the interaction develops, for example, in the context of a collaborative innovation project. These concepts are therefore relevant from an openness point of view.

The second research question concerns openness in relationship connections (Pedersen, 1996). What effects do the connections have on links, ties and bonds? All participants in a collaborative innovation project belong to business networks where they have relationships with other actors (e.g. customers and suppliers). The relationships can be connected, that is, what happens in one relationship may affect what happens in another relationship, and vice versa. The amount of effects can be interpreted in terms of openness. The interaction taking place within a certain relationship can lead to increasing, decreasing or changing interaction in other relationships. This can be manifested through strengthening or weakening of links, ties and bonds.

\section{Method}

This paper is based on a case study approach. It is particularly useful when studying relationship and network phenomena because it provides the advantage of being "close to the studied objects (firms), enabling inductive and rich description" (Halinen and Törnroos, 2005, p. 1286). Case studies are also able to provide a many-sided description of the studied phenomenon in its context relying on multiple sources of data (Easton, 2010). Case studies can be used for many purposes, including exploring and developing new theory (Halinen and Törnroos, 2005; Dubois and Gadde, 2002; Goffin et al., 2019).

\subsection{Multiple case study consisting of historical and contemporary cases}

Eisenhardt and Graebner (2007) stress the usefulness of the multiple case study approach for theory building. It has the advantage of enabling comparisons that clarify whether the phenomenon is specific to one case or grounded in a more varied empirical material. Cases can be historical or contemporary (ibid.). In this paper, we use a combination of five historical and contemporary cases. The studied companies have been involved in collaborative product development projects where two or more actors have interacted with each other and contributed to the outcome. We have chosen these particular cases based on their variety (Aaboen et al., 2012) in terms of openness. The cases were selected among a larger number of INA-based case studies that we have carried out 
over a long period of time, spanning several decades. Hence, taken together, these cases in different ways illustrate typical interaction patterns, thereby enabling us to investigate how the concept of openness can help us to enhance understanding of collaborative innovation in industrial networks.

There are three contemporary cases, taking their starting point in three focal firms: SKF, Loccioni and Oxeon. Two historical cases of collaboration that took place many years ago are also included: Nippon Steel - Toyota and Pharmacia Biotech - Seiko. These cases strikingly illustrate certain important aspects of openness and therefore constitute a fruitful complement to the contemporary cases. In addition, these cases clearly show that managing openness in collaborative innovation is not a new issue. All five cases deal with supplier-customer collaboration in product development. There is variety in terms of industry and type of product, the geographical location of the focal companies and the number of actors involved.

\subsection{Data collection and analysis}

The data collection is mainly based on semi-structured interviews with key managers in the focal companies and sometimes with representatives of partners. The interviews have been carried out during different time periods, sometimes many years ago (1990s) and sometimes more recently. We have in total interviewed 35 people, including, for example, $R \& D$ directors, marketing managers, project managers, and senior executives. Besides the original interviews, we have had followup contacts with previous or new respondents, giving us an opportunity to receive updated and complementary information. For all cases, there are previous publications building on the initially collected data. The case versions included in this paper have been written to fit the present purpose and as explained sometimes use new data.

The cases describe the collaborative innovation projects with a main focus on openness aspects. The subsequent analysis focuses on similarities and differences aiming to explore the meaning of openness from an INA perspective. In analyzing each case, we have taken starting points in the presented case descriptions and searched for constructs that could help to explain openness: the result was business relationships and their connections. The analytical comments ending each case were helpful for spotting unique aspects and for identifying variety across cases.

\section{Case studies}

We present the cases in the following order: SKF, Nippon Steel - Toyota, Pharmacia Biotech - Seiko, Loccioni and Oxeon. As is apparent from the analytical comments, where we highlight interesting observations, we have found this order to be purposeful.

\subsection{SKF and customer collaboration}

$\mathrm{SKF}$ is a world-leading bearing manufacturer headquartered in Sweden. It carries out a broad range of innovation activities, some of which involve external actors to varying extent (LaageHellman and Lind, 2012). Here, we will describe two types of product development projects that are particularly interesting from an openness point of view: customer-driven projects and segment-driven projects.

\subsubsection{Customer-driven product development}

"Customer-driven projects" aim to develop New Customer Offers that take their starting point in problems or needs expressed by a single buyer. There can be uncertainty, for example, regarding what is wrong with the existing solution and/or how to make a new solution. Such situations necessitate joint $\mathrm{R} \& \mathrm{D}$ efforts. It can be, for example, an automotive company developing a new car or truck model and looking for a new solution consisting of a complete bearing unit. For SKF, these projects are often large and characterized by a high degree of uncertainty. SKF desires that the risks as well as the rewards are shared. It may take several years to complete the project, and it typically involves a large number of people from both companies. The interaction through which both parties pool different tangible and intangible resources continues throughout all phases of the development process. At SKF, there is often a unique production line set up for the customer.

For SKF, it is important that the customer is actively involved in all phases, including conceptualization, detailed design and testing. A condition for a successful outcome is that both parties are open to each other, which means that they are willing to share information and participate in the development work. It is also important that the involved personnel from SKF have good personal relations with their counterparts in the customer firm. This facilitates solving various problems that may come up. Furthermore, to enable the desired communication, SKF always signs a development contract with the partner that includes a non-disclosure agreement. This means that neither SKF nor the customer can pass on information obtained from the partner to a third party.

As a rule, the solution belongs to the customer, and normally SKF cannot offer it to other buyers. Nonetheless, SKF may sometimes, thanks to the work carried out together with the partner, learn some more general lessons that it can apply internally, for example when developing a more standardized product for an entire market segment.

Whether a certain project becomes successful or not is heavily dependent on the customer's attitudes and perceptions. If the customer does not see the project as part of a long-term partnership, then it may be difficult to mobilize the necessary commitment from the customer.

\subsubsection{Segment-driven product development}

This kind of project differs from the previous one in terms of how customers are involved. The segment-driven projects take their starting point in general industry/market needs or trends within a specific market segment. It may be, for example, windmills, wheel hubs for agricultural machines or continuous casting of steel. The aim is to develop a solution (New Market Offer, NMO) for all customers in the segment. The development is thus driven by customer needs, but the projects are not initiated by and carried out on behalf of an individual customer. Windmills exemplify a segment that is important to $\mathrm{SKF}$ and where there is a great need for development. For example, there have been numerous breakdowns of large offshore windmills caused by bearing-related problems. For SKF, being a leading supplier to the windmill industry, this has created interesting business opportunities and given incentives to develop new solutions such as a totally new turbine for offshore applications. 
In segment-driven projects, customers are typically involved in the early and late phases of the product development process. Hence, in the technical feasibility phase, SKF is assisted by customers in making requirement specifications. Among other tools for identifying and verifying customer needs, the NMO team often carries out a Quality Function Deployment exercise where it visits and talks to a limited number of selected customers. The collected information is subsequently translated by the team into technical parameters and more precise development goals.

In this kind of project, customers are rarely involved in the design and verification phase where the development work is mainly carried out internally. But after having completed this phase, to validate the product, finalize the design and prepare for launching, SKF tries to sell the solution to a small number of pilot customers. These should ideally be firms having the problem to be solved and being willing to collaborate with SKF in testing the product in their own plants or products. SKF strives to work in parallel with a handful of pilot customers, for example representing different applications or use conditions. These development activities are not directly connected, that is, each collaboration can be characterized as dyadic. Test results as well as other experiences and viewpoints are fed back to SKF and used to finetune the design. In contrast to the customerdriven projects, the partners are not granted exclusive rights to the solution. The result in the form of a final product design and applications becomes part of the NMO directed at all buyers in the segment. For the pilot customers, the advantage of participating in such projects is that they gain early access to the solution and a head start over their competitors.

\subsubsection{Analytical comment}

This case shows that collaborative innovation projects can be either dyadic or have a multi-actor character. The former category, here represented by SKF's customer-driven projects, is "special" in the sense that it involves only two actors, usually a seller and a buyer which jointly develop a new customerspecific product or application. The two companies have all the key resources necessary to carry out the development work and there is no need and desire to bring in resources from and involve other "third-party" actors.

The segment-driven projects have a multi-actor character, meaning that SKF interacts in parallel with several customers, both in the early and late phases. However, the number of partners is limited. It would not be possible, for example, to have testing going on with too many pilot customers at the same time. SKF's collaboration tends, for understandable reasons, to be more intensive in customer-driven projects. Another difference is that in such projects, the collaboration activities stretch over all phases of the development process.

\subsection{Nippon Steel - Toyota}

Nippon Steel Corporation in Japan is one of the world's largest steel makers. Toyota Motors is Nippon Steel's largest customer, buying a range of different products. This includes coated steel sheet used for making autobodies. In the late 1980s, Nippon Steel and Toyota initiated a joint R\&D project aiming to develop a new type of sheet with enhanced corrosion resistance (Laage-Hellman, 1997, for a longer case description). The project took its starting point in an invention made in one of Nippon Steel's laboratories and aimed at developing a product adapted to Toyota's specific needs. After five years of intensive R\&D collaboration, the two companies had succeeded in developing a product, called Durexcelite, the manufacturing process and knowledge about how to use the steel sheet for making autobodies. The new solution satisfied Toyota's current needs. Both companies invested large resources in the development work. A large number of people representing different functions such as $\mathrm{R} \& \mathrm{D}$, manufacturing, purchasing and marketing - were involved and communicated frequently with each other. In total, there were 15 people from Nippon Steel and 25-30 from Toyota who worked on the project. Thanks to the frequent meetings and strong personal ties that emerged, effective exchange of knowledge could take place.

After extensive field testing on Toyota cars, Durexcelite was successfully implemented in Toyota's production, starting with one model followed by others. To enable large-scale production of Durexcelite, Nippon Steel had to build a new galvanizing line.

Some years after the project started, Nippon Steel and Toyota realized that Durexcelite would become an important innovation to which both parties had made substantial contributions. Until then, the collaboration had been informal, building on trust. But to make clear how the ownership of the intellectual properties should be divided and under what conditions the innovation could be used, a detailed agreement was made. It took into consideration the interests of both parties, which for natural reasons were partly conflicting. The negotiations were tough but took place in a friendly atmosphere. Nippon Steel had invested large resources both in $\mathrm{R} \& \mathrm{D}$ and in the new plant and wanted also to sell Durexcelite to other customers. This included some of Toyota's competitors. It was agreed that after five years, Nippon Steel would be allowed to sell Durexcelite to other customers on condition that these bought a license from Toyota. Thus, there was a delay enabling Toyota to have exclusive rights for a number of years. At the same time, Toyota pursued a dual sourcing strategy and wished to buy the same product from several Japanese steel makers. It was agreed that with a delay of four years, Nippon Steel would allow domestic competitors to buy a license to make Durexcelite. These solutions were satisfactory to both parties.

The experience of the Durexcelite project was very positive, and this led Nippon Steel and Toyota to establish a permanent organizational structure for carrying out collaborative innovation projects. It included the formation of joint groups on different levels for exchange of information as well as for initiation and execution of new development activities. This has worked well and contributed to deepening the relationship. In the field of coated steel sheet, for example, Nippon Steel and Toyota over several decades with a 5-6year interval have jointly developed a series of new products based on different coating technologies with gradually improved properties. These projects were thus carried out in a similar manner as the Durexcelite project.

\subsubsection{Analytical comment}

This example of dyadic development is similar to SKF's customer-driven projects. However, this case is extreme given 
its intensity in terms of the amount of resources invested and the number of people involved. Furthermore, the collaboration is also very long-lasting, because the described project was followed by several consecutive projects where the two companies continued to develop new products together.

The case also illustrates that despite the dyadic character of the development process, other actors were offered the opportunity to use the innovation at a later point in time. This kind of outcome where use is broadened is rare in the case of SKF's customer-driven projects.

We also note that from the beginning, the interaction was informal. As was shown by Håkansson (1990), technical collaboration between sellers and buyers in B2B markets is predominantly informal and this informal pattern is still valid (Laage-Hellman et al., 2018). However, this case shows how the parties, given the size and complexity of the project, chose to formalize the collaboration legally and organizationally and made it more long-sighted. In the case of SKF's customerdriven projects, which are relatively frequent, the signing of a detailed contract has become routinized.

\subsection{Pharmacia Biotech - Seiko Instruments}

In the early 1990s, Pharmacia Biotech, an internationally leading Swedish manufacturer of biotech tools, was developing a new highly automated DNA sequencer. It had chosen to initiate a collaboration with Seiko Instruments Inc. in Japan for the purpose of developing an advanced materials handling robot to be included in Pharmacia's sequencing system (LaageHellman, 1996, Ch. 7 for a longer case description).

Some years earlier, Seiko had begun to develop a robot that could handle a large number of samples and chemical reagents. Pharmacia heard about this and became interested in letting Seiko develop a robot that fitted its own needs. This was a large and complex development project that lasted for several years. For Seiko, being a specialist in instrument manufacturing that lacked in-depth chemical and biological competencies and a distribution channel in the biotech market, collaboration with Pharmacia offered an opportunity to commercialize its robot technology. After intensive negotiations, a deal was concluded according to which Seiko was to develop a robot adapted to the needs of Pharmacia. This required certain modifications to the technology and a redesign of the existing product in line with preliminary specifications presented by Pharmacia. But Seiko, despite great efforts, failed to develop a solution that met Pharmacia's requirements. There were several technical problems that had not been solved and which affected the performance of the robot when connected to Pharmacia's sequencer. A major reason for this failure had to do with the parties' view on the deal and what kind of relationship that was required. Key individuals in both companies saw the deal as "an ordinary Original Equipment Manufacturer (OEM) contract" where Seiko would develop a solution based on Pharmacia's specifications. This attitude meant that the communication on the operative level was too limited and not sufficient to solve the problems. Seiko's task was difficult given that the requirements for the robot changed several times during the project, and this led to changing specifications. Moreover, Seiko lacked application knowledge in the biotech field.
We conclude that to cope with these challenges and enable the development of a robot with appropriate design and function, a closer collaboration regarding the technical aspects should have taken place. Both companies should have made stronger commitments and been prepared to invest larger resources in joint activities. Instead of viewing each other as parties in an OEM deal, they should have realized that this was a collaborative development project that required a different type of relationship. If the two companies had joined forces and pooled their respective expertise, it is likely that the technical problems could have been solved. In other words, the lack of openness in the relationship, in terms of information exchange and joint problem-solving, prevented an effective interaction characterized by a true co-development spirit from taking place.

Even though both companies were operating internationally, the long geographical distance between Seiko and Pharmacia Biotech's headquarters in Sweden had some negative effects on the personal communication. Pharmacia Biotech's subsidiary in Japan became involved and tried to bridge the distance, geographically and culturally, but this did not help. In the end, because of the lack of a well-functioning robot Pharmacia chose to terminate the collaboration and instead use a less innovative solution.

\subsubsection{Analytical comment}

This case illustrates a dyadic development project that did not succeed because of the lack of openness. As we see it, the failure was not primarily caused by the technological challenges. Instead, it was the way the parties acted toward each other that prevented effective interaction and resource combining from taking place. Interestingly, a sister company of Pharmacia Biotech, named Pharmacia Diagnostics, in parallel carried out a similar collaborative project with a Japanese supplier (ibid., Ch. 8). However, unlike the present, case this project became successful. We note that this relationship was quite different. The two teams in Sweden and Japan interacted intensively, both at distance and through several mutual visits. Close friendship evolved between key persons in the two companies, and this facilitated an open-minded and trustful information exchange. All the technical problems could be solved and the supplier's instrument could be successfully included in Pharmacia Diagnostics' system.

There was a written agreement based on the OEM logic, but this did not help the parties to create a purposeful interaction rather the opposite. We think that a formal agreement could have increased the likelihood of a successful outcome, but then it should have had a different content that supported the development of a collaborative relationship characterized by openness.

Pharmacia Biotech had a long tradition of successful R\&D collaboration with different types of external actors, and many of its products had come from long-term and tight collaborations with researchers and customers in academia and industry. Obviously, experience cannot always help to prevent cases like this one.

\subsection{Loccioni and multi-actor collaboration}

Loccioni - an Italian-based system integrator - in 2005 developed an analyzer named Mexus used for measuring the performance of fuel injectors for automotive engines during their manufacturing. This analyzer, a major innovation in its field, was developed and commercialized within a constellation 
of three actors, namely, besides Loccioni one of its major customers - the German injector producer Continental - and one of its suppliers - National Instruments (NI) in the USA [see Baraldi et al. (2012a), for a longer case description]. Continental in 2007 became the first user of Mexus. Later on, the product was sold also to other injector manufacturers.

It all began when Continental experienced technical problems with an existing on-the-shelf fuel-testing system delivered by Loccioni. Continental asked Loccioni to fix the problem. This event led Loccioni to start developing a totally new solution, which became Mexus. The goal was to develop a product tailored to Continental. But at the same time, Loccioni's intention was to come up with a solution that could easily be adapted to the needs of other potential customers. From the very beginning, both Loccioni and Continental understood how important it was to collaborate tightly and keep the communication channels as open as possible. Loccioni started by investigating some specific features of Continental's production line to better understand the problem that had caused the breakdown of the existing product. Several people from Continental joined the project team set up at Loccioni's headquarters. It was of great importance to the design of Mexus that Loccioni gained access to data regarding the testing and the measurement results obtained when the device was in use.

Loccioni also initiated a discussion with its supplier NI to decide which component should be selected for further development. This initiative strengthened the relationship between Loccioni and NI, and the latter became a partner in the project. NI, for example, organized technical courses that taught Loccioni's engineers how they could use a certain component platform for automatic control in the Mexus project. The intensive interaction that emerged between the two companies resulted, inter alia, in the development of new software.

An important part of the development work was to test prototypes at Continental's production site. To support the testing, for example, of the device's ability to measure the fuel flow in injectors, Continental set up a dedicated test unit. This unit proved to be a valuable resource for the project. In addition, technical people from NI participated in the testing activities, and this gave them knowledge that helped them adapt the component to measurement applications in the automotive field. For instance, the development work resulted in more robust and reliable software that solved some problems with electronic noise that had appeared.

In the end, the final version of Mexus fulfilled the needs of Continental, which became the first buyer. In line with the original plan, Loccioni after a while approached other injector manufacturers. Continental had accepted that Loccioni offered its competitors to buy Mexus, because Loccioni had borne all the $\mathrm{R} \& \mathrm{D}$ costs and had shown transparency and high commitment throughout the whole development process. Within one year, Loccioni had succeeded in selling 25 Mexus units, containing somewhat customized hardware and software, to four different injector manufacturers.

\subsubsection{Analytical comment}

This is an example of a multi-actor project involving more than two collaborating parties. The project was, however, initiated dyadically within an existing business relationship, but a third actor soon became involved.

The pattern of interaction differs from what we saw in SKF's segment-driven projects, which also have a multi-actor character. Here, all three actors carried out $R \& D$ activities together with each other, and this necessitated multi-relational coordination. Moreover, certain organizational initiatives were taken to support the interaction and enable effective combining of resources.

\subsection{Oxeon and customer collaboration}

Oxeon is a research-based start-up company which has successfully developed and commercialized a new type of fabric used in the production of carbon fiber composites. The origin of this fabric is an invention made at Chalmers University of Technology in Sweden. See Laage-Hellman et al. (2018) for a longer version of this case.

Collaboration with customers has been crucial for Oxeon's product development and growth. Soon after its foundation in 2003, Oxeon initiated collaboration with a handful of Formula 1 racing teams. These teams represented potential customers and had high expertise and a strong interest in finding new technical solutions. These teams received fabric samples which they tested in their laboratories and on their cars. The Formula 1 business is notable for fierce competition and a high degree of secrecy. Therefore, the interaction with the teams was not as open as Oxeon had wished. Nevertheless, the feedback Oxeon received from these potential customers proved to be very useful. For example, Oxeon received valuable information about how the teams designed the components and what requirements they had for the fabric. This had an important impact on the properties given to the fabric and on the design of the manufacturing process. The participating teams became Oxeon's first customers when a finished product became available after a few years.

In terms of sales potential, Formula 1 is a small application field, and to grow, Oxeon targeted other industries. Sporting goods became a natural target. Based on the results from working with Formula 1 teams, Oxeon has succeeded in establishing itself as a supplier to several leading manufacturers of such products as golf clubs, tennis rackets, surfing boards and bicycles. Oxeon could do this freely because the previous Formula 1 partners did not own any rights to the product and, moreover, did not see the sporting goods manufacturers as competitors.

The fabric sold in the sporting goods field is always customer-adapted. To develop such solutions, Oxeon has to carry out collaborative $\mathrm{R} \& \mathrm{D}$ activities together with each customer. Effective resource combining necessitates that the parties (often including the brand owner's sub-suppliers) are prepared to share proprietary technical information and engage in joint development activities regarding the fabric and its use. Oxeon may refrain from working with certain potential customers if it feels that the prospective partner does not have the right attitude and is unwilling to give away information that Oxeon needs to develop a well-functioning solution. To protect the knowledge received from the customer and the design of the solution, Oxeon's policy is to work with only one buyer for each end-product.

\subsubsection{Analytical comment}

This is another example of a multi-actor project, but it differs from the previous one. As in the case of SKF's segment-driven 
projects, Oxeon is a focal actor that, in its own product development, involves several external actors. Oxeon interacts separately with each partner - both in the early development of the fabric and in the later application development.

Oxeon is a young company but has learnt and implemented important lessons for how to manage collaborative relationships with customers. This influences its choice of partners and how it signs contracts that support the establishment of the desired type of relationship.

Oxeon's fabric has a high degree of versatility and can be used in different industries. The varying features of these industries mean that, to create effective collaboration, Oxeon has to adapt how it interacts with different types of counterparts. Thus, the prerequisites for information exchange and joint activities vary among industries.

\section{Analysis}

Here, based on our five cases, we explain how openness in collaborative innovation can be understood from a business relationship and network perspective. As stated in Section 2, we use the ARA model as a starting point. In the next sub-section, the forms and contents of openness in dyadic interaction are analyzed, followed by forms and contents of openness in relationship connections. The analysis ends with a discussion of dynamics at both levels.

\subsection{Forms and contents of openness in dyadic interaction}

How the dyadic interaction evolves in collaborative relationships is of obvious importance for the outcome of innovation projects - whether they are of a dyadic or multiactor character. We can distinguish three forms and related contents of openness.

The first form has to do with the exchange of resources, in particular knowledge, between the two parties. Resource ties arise, for example, when information is transferred in the context of a product development project where a selling and a buying firm collaborate. The goal can be a customized product or a new product for a broader market. In any case, the supplier needs to have good knowledge of the customer's needs and wants to be able to steer the own development activities in the right direction. At the same time, the customer for the same reason needs to have knowledge of the supplier's capability to design and manufacture the product. This can affect the customer's own development activities and improve the fit between the future product and its use. The creation of such ties requires openness. Thus, the parties must be prepared to share proprietary knowledge that the partner needs and spend time and money on communication activities. Such ties are clearly visible in the Nippon Steel - Toyota case and they are considered to be crucial in SKF's customer-driven projects. Sufficient openness in this respect does not come by itself. The formation of ties is dependent on the parties' attitudes to external collaboration and their understanding of what it takes to build an effective collaborative relationship.

The second form of openness pertains to the execution of joint development activities related, for example, to design or testing. This is useful especially in larger and more complex projects where information exchange is not enough. These activities lead to the establishment of links such as in the case of SKF's customer-driven projects. Here, openness means that the parties are willing to engage and invest in joint activities. These can be quite costly if, for instance, the geographical distance is long.

Besides resource ties and activity links, the effectiveness of dyadic interaction can be influenced by actor bonds, which is the third form of content. The bonds are important both for the resource exchange and the joint activities. They can be of an informal and social character, for example, when key individuals have got to know, like and trust each other. But they can also be based on formal agreements and organizational adaptations. The formation of bonds is typically an effect of the interaction, especially if the outcome is positive. At the same time, actor bonds support continued collaboration leading to a further strengthening of links and ties. We note that following the Durexcelite project, Nippon Steel and Toyota over a long period of time carried out several similar projects. This relationship is characterized by a gradual strengthening of links, ties and bonds reflecting a high degree of openness on both sides.

Links, ties and bonds do not come by themselves, which is nicely illustrated by the Pharmacia Biotech - Seiko case. The poor communication and the insufficient joint problem-solving resulting from weak links, ties and bonds were a consequence of the parties' attitudes and their view of the relationship. The reason for the malfunctioning of a relationship may be that key individuals do not fully understand how to build an effective collaboration based on mutual give and take. Or the company can have an introvert organizational culture or an inwardlooking R\&D strategy that does not favor external collaboration (Håkansson and Laage-Hellman, 1984). Also, Laage-Hellman (2012, Ch. 6) gives an example of a partnership in which the low degree of openness meant that the joint project failed.

\subsubsection{Variation of openness among projects}

A high degree of openness is important, especially in larger and more complex projects that require far-reaching resource combining based on strong links, ties and bonds. SKF's customer-driven product development projects are good examples. However, in other situations, companies may involve external actors in a more superficial way, for example when, as in SKF's segment-driven projects, they interact with a set of customers to gain a deeper understanding of user needs, or when they test products under development together with potential customers. In these interactions, there is also need for openness, but strong links, ties and bonds may not be required.

\subsection{Forms and contents of openness in relationship connections}

There are relationship connections both in dyadic and multiactor projects. In the former, both parties have relationships with other customers or suppliers and these, depending on the context, can be connected (or potentially connected) to a focal collaborative relationship. For example, when SKF is developing a new bearing solution for a certain car maker, it simultaneously has business relationships with other car manufacturers that buy similar products and might be interested in the innovation. And SKF's partner may have business relationships with other bearing suppliers. The same applies to multi-actor projects such as Mexus where Loccioni 
and its partner Continental have other parallel business relationships. In addition to this, there are connections within the project which in this case involves three companies forming a triad.

Thus, we can distinguish two types of connections - those within projects and those that may exist because of the collaborating companies' relationships with "third parties." Regarding the former category of connection, openness means that the interactions taking place in the different collaborative relationships are coupled, coordinated and allowed to affect each other. This means that activity links are created. Knowledge exchange among collaborating actors may lead to the formation of knowledge ties, for example, consisting of a partly common knowledge base founded on inputs from several actors and/or resulting from joint activities. We see these effects clearly in the Loccioni case. The three partners worked tightly together within the triad, and this led to strong ties and links, and these were important for the success of the Mexus project. It also seems that actor bonds were stimulated by the triadic interactions.

The Oxeon case represents a different kind of multi-actor project. Oxeon is a focal actor which pursued its own product development project where it collaborated with several potential customers in parallel. At an early stage, Formula 1 teams made valuable contributions. These relationships with a handful of potential customers existed in parallel and were complementary from the perspective of Oxeon. However, the customers saw themselves as competitors, which means that there were no direct connections between the relationships. There was no transfer of information and no coordination of activities. That is, there was no openness at all between the relationships. Rather, we can say that the connections were characterized by closeness, that is to say, complete absence of openness. The same type of closeness exists in Oxeon's current collaborations with customers in the sporting goods industry. Here, Oxeon has chosen to work with one OEM for each product category. Other manufacturers of the same type of product are prevented from buying Oxeon's fabric. This is an illustration of the second type of connection, the involvement of third parties. In this particular case, there is closeness in relation to other potential buyers.

The exemplified closeness toward other actors outside of the collaborative project is understandable and common in B2B markets. However, there are exceptions to this pattern, which is illustrated, again, by the Loccioni case. Here, Loccioni developed a new product aimed at solving Continental's problem with the existing analyzer. The final design was optimized to meet Continental's needs and was the result of intensive collaboration. Nonetheless, it had been decided at an early stage that Loccioni would be allowed to sell Mexus to other fuel injector manufacturers. These connections resulted in activity links in the form of adaptations and production activities taking place in these customer relationships.

What we see in the Loccioni case is that there was closeness in the development phase, but openness in the commercial phase when there was a finished product available for sale. The possibility of Loccioni selling the new analyzer to Continental's competitors had been agreed upon at an early stage. The background was that Loccioni bore most of the development costs. The selling of the new analyzer to other injector manufacturers also gave some potential advantages to Continental such as a lower price resulting from scaleadvantages in production. Furthermore, this kind of product is important to have, but is not crucial to the user's competitiveness. By contrast, in the case of SKF, it is probably more common for the customized solutions to be perceived by SKF's partners as providing competitive advantages. The same reasoning applies to Oxeon's customers in the sporting goods industry. That is why these customers do not want the product to be offered to their competitors.

It should be noted that the term closeness (lack of openness) has relevance only on the network level. On the dyadic level, openness in a relationship can be low, as we have seen, but it does not make sense to talk about closeness between collaborating parties - then there would be no relationship.

\subsubsection{Variation of openness among projects}

As pointed out above, relationship connections tend to be closed in projects aiming to bring about customer-adapted solutions - although there can be exceptions under certain conditions (see the Loccioni case). The situation is different when it comes to projects where the goal is to develop a standardized product for a wider market. SKF's segmentdriven projects illustrate this. Here, the partners (e.g. pilot customers) are not granted exclusivity, and in the commercial phase, the use of the product is open to all buyers in the segment.

\subsection{Dynamics of openness}

The degree of openness can change over time, with regard to both dyadic interaction and relationship connections. Within collaborative relationships links, ties and bonds often grow stronger as a result of the interaction. For example, the partners may in the course of the project discover that there may be a need to coordinate certain activities to make them more effective and efficient. It is a matter of how and when the activities are carried out. Exchange of knowledge and joint generation of new knowledge can lead to strengthening of resource ties. Actor bonds, both formal and informal, naturally become stronger as a result of intensive collaborative activities, especially if these are successful. It is important that these developments are allowed to take place if there is a need. Such a need existed in the Pharmacia Biotech - Seiko case, but the partners failed to open up.

Sometimes, a new project can benefit from existing links, ties and bonds which have their origin in previous collaborations. For example, Nippon Steel and Toyota have carried out several consecutive projects in the field of coated steel sheet. When the parties have not collaborated previously, links, ties and bonds must be built from scratch. This commonly means that time and money have to be spent on relationship-building activities. This is one reason why it is often more profitable, ceteris paribus, to continue working with an existing partner, rather than switching to a new one.

Needless to say, links, ties and bonds may also become weaker as a result of the way the interaction unfolds. This happened in the Pharmacia Biotech - Seiko case as a result of a growing conflict.

Turning to relationship connections, these may also vary over time. First, within multi-actor projects, as we saw in the 
Loccioni case, the strength of links, ties and bonds within the constellation of participating partners can increase for the same reasons as discussed above. Second, the connections to other (third party) relationships can also change during the project, as illustrated by the Nippon Steel - Toyota case. The development work was carried out in a closed manner. However, in the commercial phase, the two parties agreed to open up and allow other firms to use the innovation. This was not intended from the beginning but something that resulted from the way the interaction developed.

Industrial networks are characterized by constant changes in relationships and network structures (Abrahamsen and Håkansson, 2012). The dynamic features of openness in collaborative innovation projects that we have identified in this paper are a natural element in such network development.

\subsection{Summary}

Table 1 provides a summary of the analysis results.

\section{Conclusions and propositions}

Concluding from the above, varying degrees and forms of openness can be empirically observed with regard to interaction processes in individual relationships and connections between relationships. The observed variation can be explained by differing contexts and the companies' policies and abilities.

It should be noted that our concept of openness differs from openness as commonly described in the OI literature. There, openness is the opposite of closeness, which here means a pattern where the innovation activities take place internally within the company. For us, openness instead has to do with how firms interact with other actors in collaborative projects, that is, by exchanging and combining resources and creating activity links, resource ties and actor bonds. In the OI literature, openness is seen as a new imperative for companies (Chesbrough, 2003). This view contrasts with what we have learnt through many years of INA-based research, where collaborative innovation in relationships and networks emerged as a predominant pattern of innovation in B2B markets several decades ago. Openness as described in this paper is a phenomenon that captures a range of R\&D-related interaction activities which are common when new products are developed. We postulate that this concept can be used as an analytical tool for digging deeper into relationship and network-related issues of relevance to firms' interactive behavior. Below, we formulate a set of propositions that can be taken as a starting point for future studies aiming to verify and further develop the ideas put forward in this paper:

P1a. On the relationship level, openness can be investigated in terms of activity links, resource ties, and actor bonds, which are different aspects of dyadic interaction.

P1b. On the network level, openness can be investigated in terms of relationship connections within multi-actor projects and between collaborative relationships and other relationships that the collaborating parties have with other network actors. Such connections mean that activity links, resource ties and actor bonds are affected - unilaterally or mutually.

P1c. Both the dyadic interaction and the relationship connections within multi-actor projects can be more or less open depending on how the collaborating actors choose to act. The "level" of openness is affected by the parties' policies and capabilities, and the phase (development or commercial).

We have also shown that the degree and form of openness vary - among projects and over time. There are many factors influencing the result of collaborative projects, and this includes openness issues. These observations lead us to two more propositions.

P2. What degree and form of openness that is required to make a collaborative innovation project successful depends on project characteristics - such as the type of

Table 1 Openness and closeness in collaborative innovation

\begin{tabular}{ll}
\hline Openness and closeness & Dyadic interaction \\
\hline Form and content of openness & The existence of links, ties and bonds within \\
a collaborative relationship \\
Examples: SKF's customer-driven projects; \\
Nippon Steel - Toyota
\end{tabular}

Form and content of closeness

Dynamics of openness and closeness
Increasing/decreasing links, ties and bonds within a collaborative relationship Examples: Nippon Steel - Toyota; Pharmacia Biotech - Seiko

\section{Relationship connections}

Existence of links, ties and bonds among participants in multi-actor projects

Example: Loccioni

Existence of links, ties and bonds in third-party relationships Example: SKF's segment-driven projects

Keeping different collaborative relationships apart, e.g. in multi-actor projects

Examples: Oxeon; Nippon Steel - Toyota

Exclusion of third parties from participating

Examples: SKF's customer-driven projects; Oxeon

Increasing/decreasing links, ties and bonds within a multi-

actor project

Example: Loccioni

Exclusion of third parties in development and opening up in the commercial phase

Examples: Nippon Steel - Toyota; Loccioni 
product and the actors' goals and policies - and the characteristics of the business network.

The openness within a project is not given once for all but tends to change over time depending on how the collaborating actors behave in relation to each other and to third parties.

P3. The degree and form of openness is not static but can change over time as a result of how the interaction develops in terms of activity links, resource ties and actor bonds.

\section{Implications and future research}

\subsection{Managerial implications}

Companies need to know what kind and degree of openness is required or desirable and how to create and maintain the openness. First, they have to decide how open they should be in different situations. As already suggested, it can be advantageous to have some kind of policy on this. Second, companies must be capable of handling the openness in practical situations.

Regarding the policy issue, the need for openness varies depending on project type (e.g. customized versus standardized product). The cases show that several firms have at least implicit policies that build on their experiences and seem to be helpful. When managing dyadic interaction, firms can have guidelines for what knowledge should be shared and on what conditions, and what knowledge that should be kept secret. The question is also what demands for openness the company should have for its partners, as a pre-condition for establishing collaboration.

Relationship connections also have to be managed. For example, if a selling company wants to broaden sales in the commercial phase, it is advantageous if this issue can be sorted out in advance. It also affects how the company should act within the collaborative relationship (e.g. with regard to costs, responsibilities and IP). The handling of other connected business relationships may also need to be adjusted, for example, with regard to referencing, information dissemination and monetary compensation.

Moving to the capability issue, when implementing a chosen explicit or implicit policy, firms must have appropriate competency that enables them to keep control of the collaborative activities from an openness point of view (Lichtenthaler, 2011). This capability is part of the broader relationship competencies that firms need to act successfully in industrial networks (Ritter, 1999). If $\mathrm{R} \& \mathrm{D}$ collaboration is important, this need for competency should be considered when recruiting and training new personnel. Some of our cases illustrate that the openness is not always well managed and that this can have a negative impact on the outcome of collaboration.

There is overlap between the empirical phenomena dealt with in the OI and INA literature (Öberg, 2016), but the meaning of openness differs. We think that there is a potential for OI scholars to learn from INA-based studies. For example, the OI view is firm-centric and based on the assumption that it is the focal firm that controls the process. In industrial networks, by contrast, the individual firm has limited freedom to control and therefore must adapt its own action taking into consideration the interests of the counterparts. Although each company has its own goals and ambitions, it cannot unilaterally manage its relationships and the surrounding network. Instead, it can manage in the network through its interaction activities (Håkansson and Snehota, 1995; Håkansson and Waluszewski, 2002).

\subsection{Future research agenda}

In Section 6, we presented some conclusions and theoretical implications, summarized in the form of propositions. These can be taken as starting points for future research on collaborative innovation in industrial networks. This can include studies focusing on specific openness issues raised in this paper. One possible topic is the dynamics of openness. For example, does the development of openness follow a certain progressive scale reflecting the formation of resource ties, activity links and actor bonds? Another example concerns the problematization of openness from a resource-interaction perspective. Combining and assembling resources assume importance when new technologies - or even new ventures are formed. To what extent does openness affect the resource interactive mechanism? And how? Taking the new venture perspective on openness is another possible topic. For example, how would a start-up deal with openness without having established a priori business relationships and achieved an identity in the network?

We have discussed some managerial implications. To gain a better understanding of managerial challenges and solutions implemented by firms, there is a need for deeper and more systematic studies of firms' interactive behavior. For example, what kind of openness policies do firms pursue under different circumstances? And what competencies do firms need and how can these be acquired? These questions can thus be part of a research agenda aiming to generate new knowledge about collaborative innovation in industrial networks.

\section{References}

Aaboen, L., Dubois, A. and Lind, F. (2012), "Capturing processes in longitudinal multiple case studies", Industrial Marketing Management, Vol. 41 No. 2, pp. 235-246.

Aaboen, L., La Rocca, A., Lind, F., Perna, A. and Shih, T. (Eds) (2017), Starting up in Business Networks: why Relationships Matter in Entrepreneurship, Palgrave Macmillan, London.

Abrahamsen, M.H. and Håkansson, H. (2012), "Networks in transition", IMP Fournal, Vol. 6 No. 3, pp. 194-209.

Alchian, A.A. and Demsetz, H. (1972), "Production, information costs, and economic organization", American Economic Review, Vol. 62 No. 5, pp. 777-795.

Alisghar, O., Rose, E.L. and Chetty, C. (2019), "Building absorptive capacity through firm openness in the context of a less-open country", Industrial Marketing Management, Vol. 83, pp. 81-93.

Bahemia, H. and Squire, B. (2010), "A contingent perspective of open innovation in new product development projects", International fournal of Innovation Management, Vol. 14 No. 4, pp. 603-627.

Baraldi, E., Gregori, G.L. and Perna, A. (2012a), "Exploring the conditions for marketing an innovative and unique 
customized solution: Mexus case study", The IMP fournal, Vol. 6 No. 1, pp. 1-16.

Baraldi, E., Gressetvold, E. and Harrison, D. (2012b), "Resource interaction in inter-organizational networks: foundations, comparison, and a research agenda", fournal of Business Research, Vol. 65 No. 2, pp. 266-276.

Baraldi, E., Havenvid, M.I., Linné, A. and Öberg, C. (2019), "Start-ups and networks: interactive perspectives and a research agenda", Industrial Marketing Management, Vol. 80, pp. 58-67.

Bidault, F., Despres, C. and Butler, C. (1998), "The driver of cooperation between buyers and suppliers for product innovation", Research Policy, Vol. 26 No. 7/8, pp. 719-732.

Biemans, W.G. (1992), Managing Innovation within Networks, Routledge, London.

Chesbrough, H.W. (2003), Open Innovation: The New Imperative for Creating and Profiting from Technology, Harvard Business School Press, Boston.

Chesbrough, H.W. and Bogers, M. (2014), "Explicating open innovation: clarifying an emerging paradigm for understanding innovation", in Chesbrough, H., Vanhaverbeke, W. and West, J. (Eds), New Frontiers in Open Innovation, Oxford University Press, Oxford, pp. 3-28.

Chesbrough, H.W., Lettl, C. and Ritter, T. (2018), "Value creation and value capture in open innovation", fournal of Product Innovation Management, Vol. 35 No. 6, pp. 930-938.

Cohen, W. and Levinthal, D. (1990), "Absorptive capacity: a new perspective on learning and innovation", Administrative Science Quarterly, Vol. 35 No. 1, pp. 128-152.

Cooke, P. (2001), "Regional innovation systems, clusters, and the knowledge economy", Industrial and Corporate Change, Vol. 10 No. 4, pp. 945-1974.

Dahlander, L. and Gann, D.M. (2010), "How open is innovation?", Research Policy, Vol. 39 No. 6, pp. 699-709.

Drechsler, W. and Natter, M. (2012), "Understanding a firm's openness decisions in innovation", fournal of Business Research, Vol. 65 No. 3, pp. 438-445.

Dubois, A. and Araujo, L. (2006), "The relationship between technical and organisational interfaces in product development”, IMP fournal, Vol. 1 No. 1, pp. 21-38.

Dubois, A. and Gadde, L.-E. (2002), "Systematic combining: an abductive approach to case research", Fournal of Business Research, Vol. 55 No. 7, pp. 553-560.

Easton, G. (2010), "Critical realism in case study research", Industrial Marketing Management, Vol. 39 No. 1, pp. 118-128.

Edquist, C. (Ed.) (1997), Systems of Innovation: Technologies, Institutions, and Organizations, Frances Pinter, London.

Eisenhardt, K.M. and Graebner, M.E. (2007), "Theory building from cases: opportunities and challenges", Academy of Management fournal, Vol. 50 No. 1, pp. 25-32.

Elmquist, M., Fredberg, T. and Ollila, S. (2009), "Exploring the field of open innovation: a review of research publications and expert opinions", European fournal of Innovation Management, Vol. 12 No. 3, pp. 326-345.

Enkel, E., Gassmann, O. and Chesbrough, H. (2009), “Open $\mathrm{R} \& \mathrm{D}$ and open innovation: exploring the phenomenon", RED Management, Vol. 39 No. 4, pp. 311-316.

Ford, D., Gadde, L.-E., Håkansson, H., Snehota, I. and Waluszewski, A. (2010), "Analyzing business interaction", The IMP fournal, Vol. 4 No. 1, pp. 82-106.
Freeman, C. (1982), The Economics of Innovation, Frances Pinter, London.

Gadde, L.-E. and Snehota, I. (2000), "Making the most out of supplier relationships", Industrial Marketing Management, Vol. 29 No. 4, pp. 305-316.

Goffin, K., Åhlström, P., Bianchi, M. and Richtnér, A. (2019), "State-of-the-art: the quality of case study research in innovation management", fournal of Product Innovation Management, Vol. 36 No. 5, pp. 586-615.

Håkansson, H. (Ed.) (1987), Industrial Technological Development: A Network Approach, Routledge, London.

Håkansson, H. (Ed.) (1982), International Marketing and Purchasing of Industrial Goods. An Interaction Approach, Wiley, London.

Håkansson, H. and Waluszewski, A. (Eds) (2007), Knowledge and Innovation in Business and Industry - the Importance of Using Others, Routledge, London.

Håkansson, H. (1990), "Technological collaboration in industrial networks", European Management fournal, Vol. 8 No. 3, pp. 371-379.

Håkansson, H., Ford, D., Gadde, L.E., Snehota, I. and Waluszewski, A. (2009), Business in Networks, John Wiley \& Sons, Chichester.

Håkansson, H. and Laage-Hellman, J. (1984), "Developing a network R\&D strategy", Fournal of Product Innovation Management, Vol. 1 No. 4, pp. 224-237.

Håkansson, H. and Snehota, I. (1995), Developing Relationships in Business Networks, Routledge, London.

Håkansson, H. and Waluszewski, A. (2002), Managing Technological Development. IKEA, the Environment and Technology, Routledge, London.

Halinen, A. and Törnroos, J.-Å. (2005), "Using case methods in contemporary business networks", Fournal of Business Research, Vol. 58 No. 9, pp. 1285-1297.

Hasche, N., Linton, G. and Öberg, C. (2017), "Trust in open innovation - the case of a med-tech startup", European Fournal of Innovation Management, Vol. 20 No. 1, pp. 31-49.

Holmen, E. (2001), "Central resource-related concepts within the industrial network approach", Doctoral thesis, Copenhagen Business School.

Ingemansson, M. (2010), "Success as science but burden for business? On the difficult relationship between scientific advancement and innovation", Doctoral thesis, Department of Business Studies, Uppsala University.

Johnsen, T.E. and Ford, D. (2007), "Customer approaches to product development with suppliers", Industrial Marketing Management, Vol. 36 No. 3, pp. 300-308.

La Rocca, A. and Perna, A. (2014), "New venture acquiring position in an existing network. The case of DR motor company", The IMP fournal, Vol. 2 No. 8, pp. 64-73.

La Rocca, A. and Snehota, I. (2014), "Relating in business networks: innovation in practice", Industrial Marketing Management, Vol. 43 No. 3, pp. 441-447.

Laage-Hellman, J. (1996), International Technology Cooperation: The Case of Sweden-Fapan, Chalmers University of Technology (unpublished research report).

Laage-Hellman, J. (1997), Business Networks in Japan: Supplier-Customer Interaction in Product Development, Routledge, London. 
Laage-Hellman, J., Landqvist, M. and Lind, F. (2018), "Business creation in networks: how a technology-based startup collaborates with customers in product development", Industrial Marketing Management, Vol. 70, pp. 13-24.

Laage-Hellman, J., Lind, F., Öberg, C. and Shih, T. (2020), "Interactions between university spin-offs and academia: a dynamic perspective", fournal of Business \& Industrial Marketing, Vol. 35 No. 12, pp. 1941-1955.

Laage-Hellman, J., Lind, F. and Perna, A. (2014), “Customer involvement in product development: an industrial network perspective", fournal of Business-to-Business Marketing, Vol. 21 No. 4, pp. 257-276.

Laage-Hellman, J. and Lind, F. (2012), "Customer involvement in product development: learning from a bearing manufacturer", Paper presented at the 28th IMP Conference, Rome.

Laage-Hellman, J. (2012), "Exploring and exploiting networks for knowledge-intensive entrepreneurship", Deliverable D1.7.7 (unpublished research report for the EU project Advanced Knowledge-Intensive Entrepreneurship and Innovation for Economic Growth and Social Well-being in Europe, AEGIS).

Laursen, K. and Salter, A. (2006), "Open for innovation: the role of openness in explaining innovative performance among UK manufacturing firms", Strategic Management fournal, Vol. 27 No. 2, pp. 131-150.

Lichtenthaler, U. (2011), "Open innovation: past research, current debates, and future directions", Academy of Management Perspectives, Vol. 25 No. 1, pp. 75-93.

Lind, F. (2015), "Goal diversity and resource development in an inter-organisational project", Fournal of Business $\mathcal{E}$ Industrial Marketing, Vol. 30 No. 3/4, pp. 259-268.

Lind, F., Holmen, E. and Pedersen, A.-C. (2012), "Moving resources across permeable project boundaries in open network contexts", Fournal of Business Research, Vol. 65 No. 2, pp. 177-185.

Melander, L. (2014), Supplier Involvement in New Product Development under Technological Uncertainty, Linköping University Electronic Press.

Nelson, R.R. (1993), National Innovation Systems: A Comparative Study, Oxford University Press, Oxford and New York, NY.

Öberg, C. (2010), "Customer roles in innovations", International fournal of Innovation Management, Vol. 14 No. 6, pp. 989-1011.

Öberg, C. (2016), "Let's talk about innovation: is there a hidden potential of knowledgexchange between open innovation and IMP?”, IMP fournal, Vol. 10 No. 3, pp. 540-560.

Öberg, C. and Alexander, A.T. (2019), “The openness of open innovation in ecosystems - integrating innovation and management literature on knowledge linkages", fournal of Innovation E Knowledge, Vol. 4 No. 4, pp. 211-218.

Pedersen, A. (1996), "Utvikling av leverandorrelasjoner i industrielle nettverk: en studier av koblinger mellom relasjoner (Developmenet of supplier relationships in industrial networks: a study of connections between relationships)", Doctoral thesis, Norwegian University of Science and Technology.

Penrose, E. (1959), The Theory of the Growth of the Firm, Basil Blackwell, Oxford University Press.

Porter, M. (Ed.) (1998), Clusters and the New Economics of Competition, Harvard Business Review, Nov-Dec.

Prenkert, F., Hasche, N. and Linton, G. (2019), "Towards a systematic analytical framework of resource interfaces", Fournal of Business Research, Vol. 100, pp. 139-149.

Ritter, T. and Walter, A. (2003), "Relationship-specific antecedents of customer involvement in new product development", International fournal of Technology Management, Vol. 26 No. 5/6, pp. 482-501.

Ritter, T. (1999), "The networking company: antecedents for coping with relationships and networks effectively", Industrial Marketing Management, Vol. 28 No. 5, pp. 467-479.

Rosenberg, N. (1976), Perspectives on Technology, Cambridge University Press, Cambridge.

Rosenberg, N. (1982), Inside the Black Box: Technology and Economics, Cambridge University Press, Cambridge.

Rothwell, R., Freeman, C., Horsley, A., Jervis, P., Robertsson, A.B. and Townsend, J. (1974), "SAPPHO phase II", Research Policy, Vol. 3 No. 3, pp. 258-291.

Sundquist, V. and Melander, L. (2020), "Mobilizing resources in product development by organizational interfaces across firms, units and functions", Fournal of Business \& Industrial Marketing, Vol. 36 No. 2, available online.

Teece, D.J. (1986), "Profiting from technological innovation: implications for integration, collaboration, licensing and public policy", Research Policy, Vol. 15 No. 6, pp. 285-305.

Trott, P. and Hartmann, D. (2009), "Why 'open innovation' is old wine in new bottles", International fournal of Innovation Management, Vol. 13 No. 4, pp. 715-736.

von Hippel, E. (1988), Sources of Innovation, Oxford University Press, New York, NY.

West, J. and Bogers, M. (2014), "Leveraging external sources of innovation: a review of research on open innovation", fournal of Product Innovation Management, Vol. 31 No. 4, pp. 814-831.

\section{Further reading}

Chesbrough, H.W. (2006), "Open innovation: a new paradigm for understanding industrial innovation”, in Chesbrough, H., Vanhaverbeke, W. and West, J. (Eds), Open Innovation: Researching a New Paradigm, Oxford University Press, Oxford, pp. 1-12.

Sisodiya, S.R., Johnson, J.L. and Grégoire, Y. (2013), "Inbound open innovation for enhanced performance: enablers and opportunities", Industrial Marketing Management, Vol. 42 No. 5, pp. 836-849.

\section{Corresponding author}

Andrea Perna can be contacted at: andrea.perna@angstrom. uu.se 